\title{
HEALTH AND WELNESS PROGRAM AND NEW NORMAL LIFESTYLE OF CVSU FACULTY AND THEIR PERFORMANCE
}

\author{
Leo Augustus B. Jacob \\ Graduate School, Laguna State Polytechnic University, Sta. Crruz, Laguna
}

Article DOI: https://doi.org/10.36713/epra7487

DOI No: 10.36713/epra7487

\begin{abstract}
This study determined the health and wellness program and new normal lifestyle of faculty performance of Cavite State University (CvSU). Specifically, the study sought answers to the following questions: What is the demographic profile of CvSU faculty in terms of; age; gender; sex; position; years in service? What is the level of health and wellness awareness programs of the in terms of: stress management; smoking cessation programs; health screening; exercise program activities; nutrition education? What is the new normal lifestyle of the professor of the Cavite state university in terms of; physical distancing; frequent hand sanitation;

Wearing of face mask and face shield? What is the level of faculty performance in terms of teaching new normal lifestyle of CvSU faculty in terms of; teacher's performance (2019-2020) teaching effectiveness? Is the demographic profile has a significant effect on the faculty effectiveness performance? Is the health and wellness awareness program has a significant effect in the new normal new normal lifestyle of the faculty of CVSU?

In order to conduct this study, letters was sent to the University President Dr. Hernando D. Robles, asking permission and approval to conduct the study.

Permission from the university Dean for each department. Preparation of self-made questionnaire by the researcher followed in order to obtain the necessary data on the health and wellness awareness programs to the new normal lifestyle of Cavite State University (CvSU) faculty and their performance. The respondents of the study included approximately fifty (50) Faculty of Cavite State University in any field of specialization.

The research made questionnaires were checked by the thesis consultants. The copies were then converted and sent through google form, considering the health protocols. The study utilized a descriptive design. The main source of data which was prepared by the researcher, used a simple descriptive statistics such as T-test formula and the weighted mean to determine the mean level of the health and wellness program to the new normal lifestyle of the respondents.

The gathered information were automatically transferred into spreadsheets by google form and were given to the researcher's statistician for the treatment and analysis. The gathered data were interpreted and presented into matrix form and appropriate interpretation was made.

The result showed that there is a partial significant effect of health and wellness program on the new normal lifestyle of $\mathrm{CvSU}$ faculty and their performance, and therefore the null hypothesis stating that there is no significant effect is partially rejected, it can be inferred that there is a significant effect between them.
\end{abstract}

KEYWORDS: Health and Wellness, New normal lifestyle, CvSU (Cavite State University) faculty 


\section{SJIF Impact Factor 2021: 8.013| ISI I.F.Value:1.241| Journal DOI: 10.36713/epra2016 \\ ISSN: 2455-7838(Online) \\ EPRA International Journal of Research and Development (IJRD)

\section{INTRODUCTION}

Promoting healthy communities is at the heart of what local government is about. It means creating places and spaces that cultivate belonging, inclusion, connectedness and engagement, creating a well-planned built environment that supports healthy behaviors and choices, a vibrant social environment in which people can live, work, learn and play. In short, it means striving to create the conditions in which all citizens, no matter where they are in life, can thrive, now and in the future. While there are many influences on our lives today, it is at the local level where policies and plans are made and can directly affect the health and well-being of our citizens. Local governments have a unique role to shape the local conditions that have an impact on the health of individuals and communities.

During the COVID-19 pandemic, self-care is more essential than ever to help build and maintain a healthy immune system. Your immune system plays a complex and elegant role in promoting wellness with the vital task of helping the body to identify and respond effectively to viruses and other pathogens. But how are we going to convince and motivate ourselves to start a long-term change when it comes to health and wellness?

Individuals' motivation to change is the most significant stumbling block in health promotion and wellness. Many companies are finding that health promotion programs are not achieving significant or lasting changes in health behavior. The role of wellness incentives is to motivate those who are not intrinsically motivated to participate in Wellness programs and/or adopt healthy behaviors. After all, intrinsically motivated people do not need Wellness initiatives-they will do it on their own! The size of this group is usually also affected by the novelty effect that occurs when the program is new. However, this group is usually a hard sell when it comes to any form of health promotion or Wellness, Chapman et. al (2012).

Our local government unit launch a health and wellness program for the citizen of the community of their vicinity to helps the individual to maintain the state of the art in building a health promotion programs that will benefit all individuals. Strong communities provide the essential social infrastructure necessary for individuals and families to attain well-being. Social well-being encompasses two components: basic needs such as nutrition, housing, sufficient income, and public health and safety; and, opportunities for learning, faith, recreation, creativity and artistic expression, community identity, citizen engagement and cooperation. To help meet these needs, local government, senior governments, and community stakeholders must continue to work in partnership.

Through this, a study of the health and wellness program and new normal lifestyle of CVSU faculty and their performance, the researcher wants to determine the new normal lifestyle of the Faculty in Cavite State University.

\section{OBJECTIVES}

This study determined the health and wellness program and new normal lifestyle of CvSU faculty and their performance. Specifically, the study sought answers to the following questions:

1. What is the demographic profile of Cavite State University (CvSU) faculty in terms of;

1.1 Age;

1.2 Gender;

1.3 Sex;

1.4 Position;

1.5 Years in Service?

2. What is the level of health and wellness programs of the in terms of:

2.1 Stress management;

2.2 Smoking cessation programs;

2.3 Health Screening;

2.4 Exercise Program Activities;

2.5 Nutrition Education?

3. What is the new normal lifestyle of Cavite state university faculty in terms of;

3.1 Physical distancing;

3.2 Frequent hand sanitation;

3.3 Wearing of face mask and face shield?

4. What is the level of Cvsu faculty performance in the new normal in terms of;

4.1 Teacher's Performance (2019-2020) 


\section{EPRA International Journal of Research and Development (IJRD)}

4.2 Teaching Effectiveness

5. Is the demographic profile has a significant effect on the faculty effectiveness performance?

6. Is the health and wellness program has a significant effect in the new normal lifestyle of CVSU faculty?

\section{METHODOLOGY}

The researcher consulted her statistician on the sampling techniques. Purposive sampling, also known as judgmental, selective, or subjective sampling, is a form of non-probability sampling in which researcher rely on their own judgment when choosing members of the population to participate in their study. This sampling method requires researchers to have prior knowledge about the purpose of their studies so that they can properly choose and approach eligible participants. Researchers use purposive sampling when they want to access a particular subset of people, as all participants of a study are selected because they fit a particular profile. Each individual was chosen entirely by chance and each member of the population has an equal chance of being included fifty (50) Facuty members of the Cavite State University in any field of specialization.

In order to conduct this study, letters was sent to the University President Dr. Hernando D. Robles, asking permission and approval to conduct the study.

Permission from the university Dean for each department. Preparation of self-made questionnaire by the researcher followed in order to obtain the necessary data on the health and wellness programs and new normal lifestyle of CvSU faculty and their performance.

The researcher-made questionnaire was checked by the thesis adviser. The copies were then converted and sent through google form, considering the health protocols. Face validation of the contents of the questionnaire was done by the adviser of the researcher and other panel members in the researchers list. They are vital panel members of the research department.

The gathered information were automatically transferred into spreadsheets by google form and were given to the researcher's statistician for the treatment and analysis. The gathered data was interpreted and presented in matrix forms and appropriate interpretation was made.

The following statistical tools were used in order to analyze and interpret the gathered data:

Descriptive statistics were applied to properly derive information and frequency distributions of the gathered data.

The respondents were identified using the Slovin's formula. The answers of the respondents on the evaluation about the conducting study of the health and wellness program and new normal lifestyle CvSU faculty and their performance were analyzed. Weighted mean - used to find out the average responses of the respondents as measurement of the central tendency. T-test is used to know if there is a significant effect to the new normal lifestyle of Cvsu faculty and their performance.

\section{RESULTS AND DISCUSSION}

This chapter deals with the presentation, analysis and interpretation of data gathered to answer the sub problem relative to the main problem of this study on health and wellness program and new normal lifestyle of CvSU faculty and their performance. This part discusses the findings of the study based on the research questions. 


\section{EPRA International Journal of Research and Development (IJRD)}

Status of Profile of Cvsu Faculty in Terms Of Age

Figure 1 below Demographic Profile of the Faculty of Cavite State University in terms of Age.

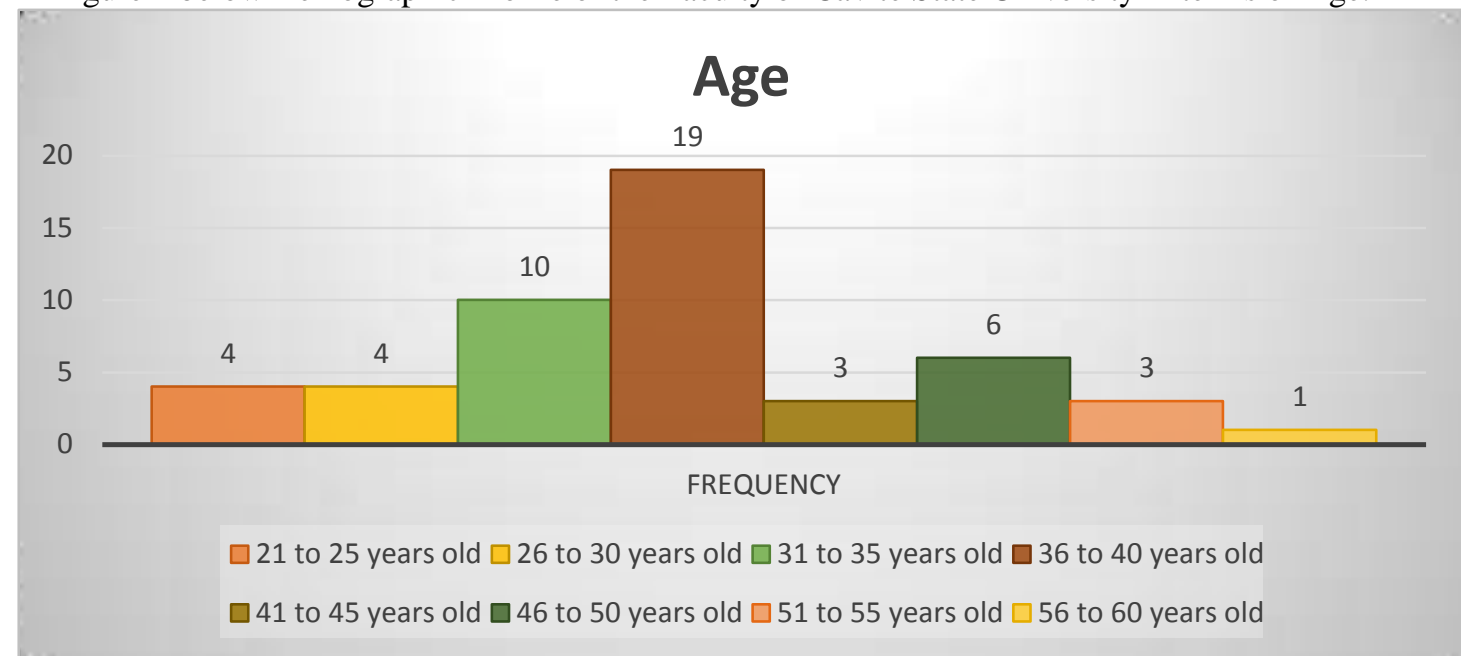

Figure 1. Demographic Profile of the CvSU faculty in terms of Age

Graph shows that ages "36 to 40 years old" have the highest frequency of nineteen (19) or $38.00 \%$ of the total respondent. And have ten (10) or $20.00 \%$ of the respondent are "31 to 35 years old". While the ages "56 to 60 years old" received the lowest frequency of one (1) or $2.00 \%$ of the total respondents.

This means that the demographic Profile of the Faculty of Cavite State University in terms of Age were majority young adolescent during the time of the study.

\section{Demographic Profile of CvSU faculty}

Figure 2 below shows the result on the Demographic Profile of CvSU faculty in terms of Sex;

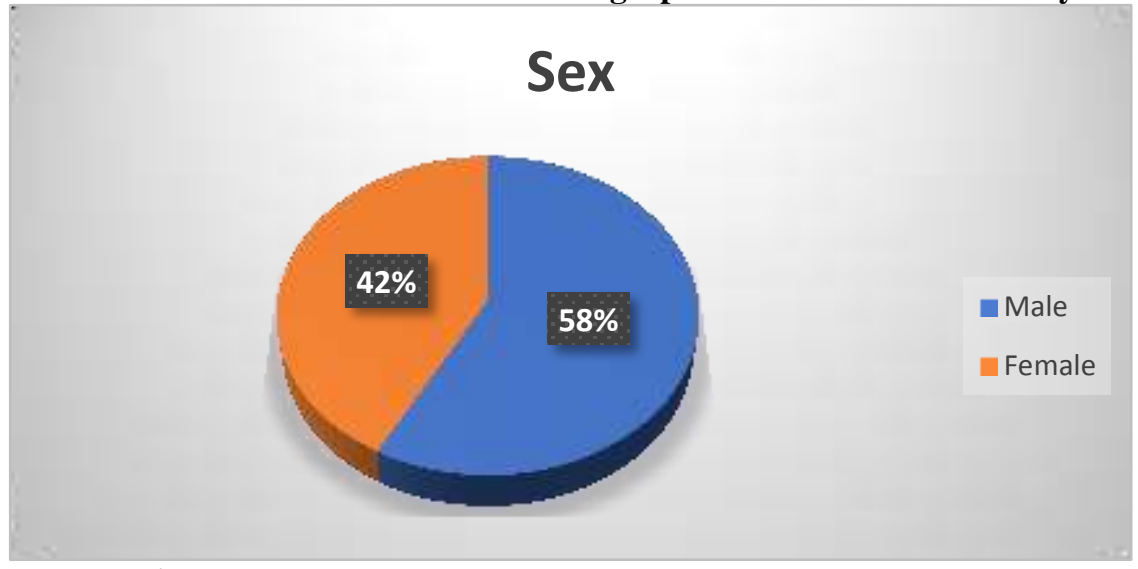

Graph shows that sex "Male" has the highest frequency of twenty-nine (29) or 58.00\% of the total respondent. While the sex "Female" received the lowest frequency of twenty-one (21) or $42.00 \%$ of the total respondents. 


\title{
EPRA International Journal of Research and Development (IJRD)
}

\author{
Volume: 6 | Issue: 7 | July 2021
}

- Peer Reviewed Journal

\section{Demographic Profile of CvSU Faculty}

Figure 3 shows the result on the Demographic Profile of CvSU faculty in terms of Gender.



Graph shows that gender "Masculine" has the highest frequency of twenty-seven (27) or 54.00\% of the total respondent. And have nineteen (19) or 38.00\% of the respondent are "Feminine". While the gender "Gay" and "Lesbian" received each the lowest frequency of two (2) or $4.00 \%$ of the total respondents

This means that the demographic Profile of CvSU faculty in terms of Gender were majority masculine during the time of the study.

\section{Demographic Profile of CvSU faculty}

Figure 4 shows the result data on Demographic Profile of CvSU faculty in terms of Designation/Position.

\section{Designation/Position}



Graph shows that position "Instructor" has the highest frequency of forty-four (44) or $88.00 \%$ of the total respondent. And have three (3) or $6.00 \%$ of the respondent are "Assistant Professor". While the position "Temporary" received the lowest frequency of one (1) or $2.00 \%$ of the total respondents. 


\section{EPRA International Journal of Research and Development (IJRD)}

\section{Demographic Profile CvSU Faculty}

Figure 5 shows the Demographic Profile of CvSU Faculty in terms of Years in Service;

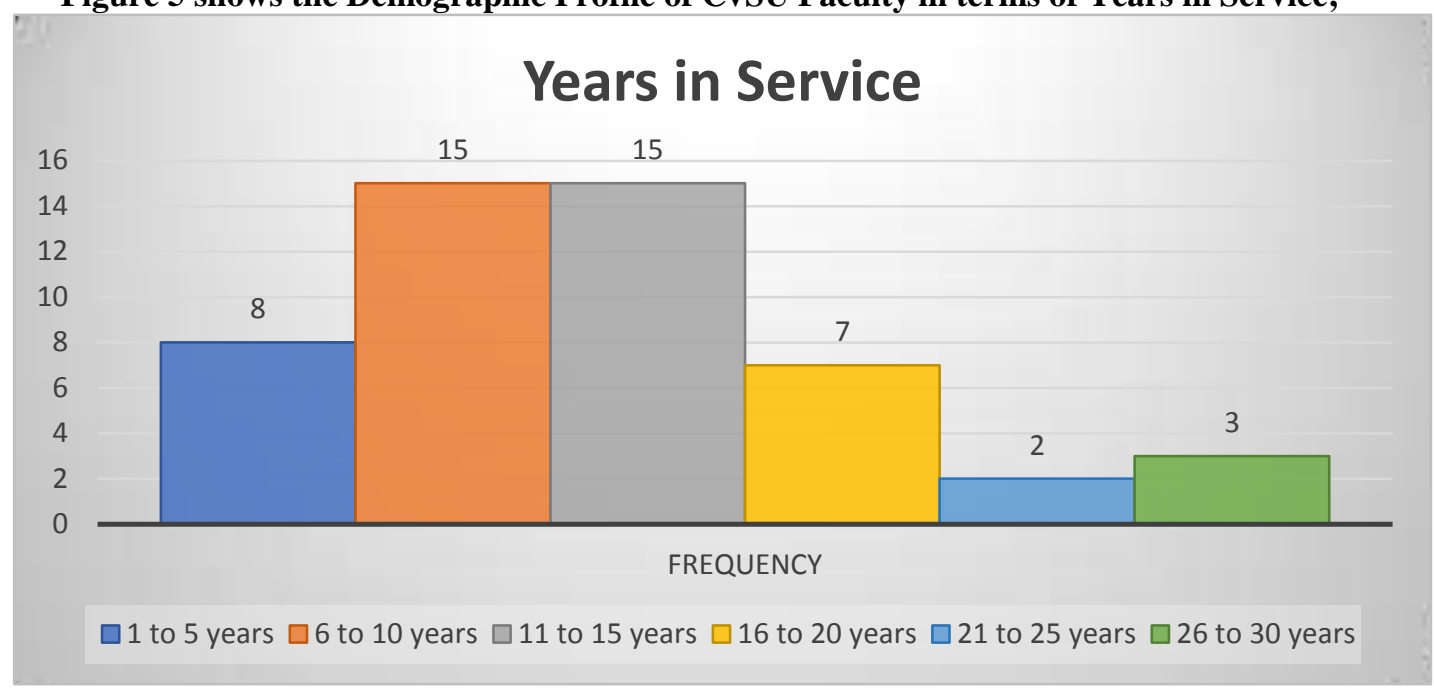

Graph shows that service "6 to 10 years" and "11 to 15 years" have each the highest frequency of fifteen (15) or $30.00 \%$ of the total respondent. And have eight (8) or $16.00 \%$ of the respondent has " 1 to 5 years". While the service "22 to 25 years" received the lowest frequency of two (2) or $4.00 \%$ of the total respondents.

\section{LEVEL OF HEALTH AND WELLNESS PROGRAMS}

Table 1. Level of health and wellness programs in terms of Stress Management

\begin{tabular}{|l|l|l|l|}
\hline $\begin{array}{l}\text { The health and wellness awareness program in terms of } \\
\text { Stress Management, the Professors were able to: }\end{array}$ & Mean & SD & Remarks \\
\hline 1. Prioritize the career and personal obligation. & 4.44 & 0.58 & Always \\
\hline $\begin{array}{l}\text { 2. Have some exercise as part of the physical activity like, } \\
\text { Zumba, jogging, biking that could relax the mind and } \\
\text { body. }\end{array}$ & 3.92 & 1.03 & Often \\
\hline 3. Small talk with trusted friend for sometimes & 4.36 & 0.75 & Always \\
\hline 4. Do some sports discipline as part of relaxation. & 4.06 & 1.00 & Often \\
\hline $\begin{array}{l}\text { 5. Go to place where we could find peace and stress } \\
\text { reliver. }\end{array}$ & 4.24 & 0.98 & Always \\
\hline $\begin{array}{l}\text { Overall Mean }=\mathbf{4 . 2 0} \\
\text { Standard Deviation }=\mathbf{0 . 8 9 8} \\
\text { Verbal Interpretation }=\text { Very High }\end{array}$ & & & \\
\hline
\end{tabular}

\section{Legend:}

Scale

5

4

3

2

1

Range
$4.20-5.00$
$3.40-4.19$
$2.60-3.39$
$1.80-2.59$
$1.00-1.79$

Remarks
Always
Often
Sometimes
Rarely
Never

Verbal Interpretation
Very High
High
Moderately High
Low
Very Low

The health and wellness program in terms of Stress Management was generally very high. They prioritize the career and personal obligation have $(\mathrm{M}=4.44, \mathrm{SD}=0.58)$ and small talk with trusted friend for sometimes with $(\mathrm{M}=4.36, \mathrm{SD}=0.75)$. They have some exercise as part of the physical activity like, Zumba, jogging, biking that could relax the mind and body with $(\mathrm{M}=3.92, \mathrm{SD}=1.03)$; and this item got the lowest rating. All item indicators got a verbal interpretation of high and very high, as disclosed by the overall mean of 4.20 and supported with standard deviation value of 0.898 . 


\section{EPRA International Journal of Research and Development (IJRD)}

\section{LEVEL OF HEALTH AND WELLNESS PROGRAMS}

Table 2. below shows the result on the Level of health and wellness programs in terms of Smoking Cessation Programs.

\begin{tabular}{|l|l|l|l|}
\hline $\begin{array}{l}\text { The health and wellness awareness program in terms of } \\
\text { Smoking cessations, the Professors were able to: }\end{array}$ & Mean & SD & Remarks \\
\hline 1. Get motivated to find a good reason to quit smoking. & 3.70 & 1.62 & Often \\
\hline $\begin{array}{l}\text { 2. Lean on the important person that could help you to quit } \\
\text { smoking. }\end{array}$ & 3.68 & 1.61 & Often \\
\hline $\begin{array}{l}\text { 3. Divert in some relaxing activities that could forget my } \\
\text { smoking habits. }\end{array}$ & 3.82 & 1.59 & Often \\
\hline 4. Prioritized health is wealth. & 4.24 & 1.29 & Always \\
\hline $\begin{array}{l}\text { 5. Engaged of being busy in some valuable physical } \\
\text { activities. }\end{array}$ & 4.10 & 1.31 & Often \\
\hline $\begin{array}{l}\text { Overall Mean }=\mathbf{3 . 9 1} \\
\text { Standard Deviation }=\mathbf{1 . 4 9 5} \\
\text { Verbal Interpretation }=\text { High }\end{array}$ & & & \\
\hline
\end{tabular}

Legend:

$\begin{array}{llll}\text { Scale } & \text { Range } & \text { Remarks } & \text { Verbal Interpretation } \\ 5 & 4.20-5.00 & \text { Always } & \text { Very High } \\ 4 & 3.40-4.19 & \text { Often } & \text { High } \\ 3 & 2.60-3.39 & \text { Sometimes } & \text { Moderately High } \\ 2 & 1.80-2.59 & \text { Rarely } & \text { Low } \\ 1 & 1.00-1.79 & \text { Never } & \text { Very Low }\end{array}$

The health and wellness awareness program in terms of Smoking cessations was generally high. They prioritize health is wealth have $(\mathrm{M}=4.24, \mathrm{SD}=1.29)$ and engaged of being busy in some valuable physical activities with $(\mathrm{M}=4.10, \mathrm{SD}=1.31)$. They lean on the important person that could help you to quit smoking with $(\mathrm{M}=3.68$, $\mathrm{SD}=1.61$ ); and this item got the lowest rating. All item indicators got a verbal interpretation of high and very high, as disclosed by the overall mean of 3.91 and supported with standard deviation value of 1.495.

\section{LEVEL OF HEALTH AND WELLNESS PROGRAMS IN TERMS OF HEALTH SCREENING}

Table 3. Level of health and wellness programs in terms of Health Screening

\begin{tabular}{|l|l|l|l|}
\hline $\begin{array}{l}\text { The health and wellness awareness program in terms of } \\
\text { health screening, the Professors were able to: }\end{array}$ & Mean & SD & Remarks \\
\hline $\begin{array}{l}\text { 1. Monitor the blood pressure and other important health } \\
\text { monitoring. }\end{array}$ & 3.96 & 0.90 & Often \\
\hline 2. Exercise the health protocols to prevent sickness. & 4.42 & 0.84 & Always \\
\hline $\begin{array}{l}\text { 3. Find time to ask for an expert's advice in health and } \\
\text { wellness. }\end{array}$ & 4.12 & 0.98 & Often \\
\hline $\begin{array}{l}\text { 4. Informed the health workers about the mild and serious } \\
\text { health status. }\end{array}$ & 3.72 & 1.09 & Often \\
\hline $\begin{array}{l}\text { 5. Aware on the health protocols and precautionary } \\
\text { measures practicing in this new normal lifestyle. }\end{array}$ & 4.70 & 0.61 & Always \\
\hline $\begin{array}{l}\text { Overall Mean }=\mathbf{4 . 1 8} \\
\text { Standard Deviation }=\mathbf{0 . 9 5 6} \\
\text { Verbal Interpretation }=\mathbf{H i g h}\end{array}$ & & & \\
\hline
\end{tabular}




\title{
EPRA International Journal of Research and Development (IJRD)
}

\author{
Volume: 6 | Issue: 7 | July 2021
}

- Peer Reviewed Journal

Legend:

$\begin{array}{llll}\text { Scale } & \text { Range } & \text { Remarks } & \text { Verbal Interpretation } \\ 5 & 4.20-5.00 & \text { Always } & \text { Very High } \\ 4 & 3.40-4.19 & \text { Often } & \text { High } \\ 3 & 2.60-3.39 & \text { Sometimes } & \text { Moderately High } \\ 2 & 1.80-2.59 & \text { Rarely } & \text { Low } \\ 1 & 1.00-1.79 & \text { Never } & \text { Very Low }\end{array}$

The health and wellness awareness program in terms of Health Screening was generally high. They are aware on the health protocols and precautionary measures practicing in this new normal lifestyle have $(\mathrm{M}=4.70$, $\mathrm{SD}=0.61)$ and exercise the health protocols to prevent sickness with $(\mathrm{M}=4.42, \mathrm{SD}=0.84)$. They informed the health workers about the mild and serious health status with $(\mathrm{M}=3.72, \mathrm{SD}=1.09)$; and this item got the lowest rating. All item indicators got a verbal interpretation of high and very high, as disclosed by the overall mean of 4.18 and supported with standard deviation value of 0.956 .

\section{LEVEL OF HEALTH AND WELLNESS PROGRAMS IN TERMS OF EXERCISE PROGRAM ACTIVITIES}

Table 4. Level of health and wellness programs in terms of Exercise Program Activities

\begin{tabular}{|l|l|l|l|}
\hline $\begin{array}{l}\text { The health and wellness awareness program in terms of } \\
\text { exercise programs activities, the Professors were able to: }\end{array}$ & Mean & SD & Remarks \\
\hline 1. Walk, run, jog at least three times a week. & 3.94 & 1.10 & Often \\
\hline 2. Have Zumba dance at home. & 3.08 & 1.03 & Sometimes \\
\hline 3.Do the biking with friends. & 3.08 & 1.19 & Sometimes \\
\hline 3. Make use of jumping rope as part of cardio exercise. & 3.00 & 1.14 & Sometimes \\
\hline $\begin{array}{l}\text { 4. Make use of stationary bike at home for some physical } \\
\text { activities. }\end{array}$ & 2.56 & 1.40 & Seldom \\
\hline $\begin{array}{l}\text { Overall Mean }=\mathbf{3 . 1 3} \\
\text { Standard Deviation }=\mathbf{1 . 2 5 3} \\
\text { Verbal Interpretation }=\text { Moderately High }\end{array}$ & \multicolumn{4}{|l}{} \\
\hline
\end{tabular}

\section{Legend:}

\section{Scale}

5

4

3

2

1
Range
4.20-5.00
$3.40-4.19$
2.60-3.39
$1.80-2.59$
1.00-1.79

Remarks
Always
Often
Sometimes
Rarely
Never

Remarks

Never

Verbal Interpretation
Very High
High
Moderately High
Low
Very Low

Verbal Interpretation

High

Low

Very Low

The health and wellness awareness program in terms of Exercise Programs Activities was generally moderately high. They walk, run, jog at least three times a week have $(\mathrm{M}=3.94, \mathrm{SD}=1.10)$ and have Zumba dance at home and do the biking with friends with $(\mathrm{M}=3.08, \mathrm{SD}=1.03,1.19)$. They make use of stationary bike at home for some physical activities with $(\mathrm{M}=2.56, \mathrm{SD}=1.40)$; and this item got the lowest rating. All item indicators got a verbal interpretation of low to high, as disclosed by the overall mean of 3.13 and supported with standard deviation value of 1.253 .

LEVEL OF HEALTH AND WELLNESS PROGRAMS IN TERMS OF NUTRITION EDUCATION

Table 5. Level of health and wellness programs in terms of Nutrition Education

\begin{tabular}{|l|l|l|l|}
\hline $\begin{array}{l}\text { The health and wellness awareness program in terms of } \\
\text { nutrition education, the Professors were able to: }\end{array}$ & Mean & SD & Remarks \\
\hline $\begin{array}{l}\text { 1. Take time to check the nutritional facts at the back label } \\
\text { of goods / foods. }\end{array}$ & 3.70 & 1.11 & Often \\
\hline $\begin{array}{l}\text { 2. Prepare a well-balanced carbohydrates, proteins and } \\
\text { mineral food to serve. }\end{array}$ & 3.98 & 0.91 & Often \\
\hline
\end{tabular}




\section{EPRA International Journal of Research and Development (IJRD)}

\begin{tabular}{|l|l|l|l|}
\hline 3. Avoid eating food high in sugar and salt. & 3.84 & 1.00 & Often \\
\hline $\begin{array}{l}\text { 4. Take extra time to prepare the left-over food for some } \\
\text { variation. }\end{array}$ & 3.86 & 1.05 & Often \\
\hline 5. Practice meal planning. & 3.84 & 1.06 & Often \\
\hline $\begin{array}{l}\text { Overall Mean }=\mathbf{3 . 8 4} \\
\text { Standard Deviation }=\mathbf{1 . 0 2 4} \\
\text { Verbal Interpretation }=\text { High }\end{array}$ & & \\
\hline
\end{tabular}

Legend:

Scale

5

4

3

2

1
Range Remarks

4.20-5.00 Always

3.40-4.19 Often

2.60-3.39 Sometimes

1.80-2.59 Rarely

1.00-1.79 Never
Verbal Interpretation

Very High

High

Moderately High

Low

Very Low

Based on the health and wellness awareness program in terms of Nutrition Education was generally high. They prepare a well-balanced carbohydrates, proteins and mineral food to serve have $(\mathrm{M}=3.98, \mathrm{SD}=0.91)$ and take extra time to prepare the left-over food for some variation with $(\mathrm{M}=3.86, \mathrm{SD}=1.05)$. They take time to check the nutritional facts at the back label of goods / foods with $(\mathrm{M}=3.70, \mathrm{SD}=1.11)$; and this item got the lowest rating. All item indicators got a verbal interpretation of high, as disclosed by the overall mean of 3.84 and supported with standard deviation value of 1.024 .

\section{LEVEL OF NEW NORMAL LIFESTYLE OF CVSU FACULTY;}

Table 6. Level of new normal lifestyle of CvSU faculty in terms of Teaching Performance

\begin{tabular}{|l|c|c|c|}
\hline Grade & frequency & \% & Adjectival Rating \\
\hline $4.500-5.000$ & 13 & $\mathbf{2 6 . 0 0}$ & Outstanding \\
\hline $3.500-4.499$ & 25 & $\mathbf{5 0 . 0 0}$ & Very Satisfactory \\
\hline $2.500-3.499$ & 12 & $\mathbf{2 4 . 0 0}$ & Satisfactory \\
\hline $1.500-2.499$ & 0 & $\mathbf{0 . 0 0}$ & Unsatisfactory \\
\hline Below 1.499 & 0 & $\mathbf{0 . 0 0}$ & Poor \\
\cline { 1 - 2 } Total & $\mathbf{5 0}$ & $\mathbf{1 0 0 . 0 0}$ & \multirow{2}{*}{ Very Satisfactory } \\
\cline { 1 - 2 } Weighted Mean & 4.046 & & \\
\hline Lowest Grade & 3.27 & & \\
\cline { 1 - 2 } Standart Grade & 4.87 & & \\
\hline
\end{tabular}

Table 6. shows the level in new normal lifestyle of CvSU faculty in terms of Teaching Performance, out of 50 faculty, the grade "3.500-4.499" got the highest frequency of twenty-five (25) or 50.00\% of the sample population and with descriptive equivalent of Very Satisfactory. And the grade "4.500-5.000" has a frequency of thirteen (13) or $26 \%$ of the sample population and with descriptive equivalent of Outstanding. While the grade "2.500-3.499" received the lowest frequency of twelve (12) or $24.00 \%$ of the sample population and with descriptive equivalent of Satisfactory.

With the weighted mean of 4.046 and supported value of standard deviation of 0.535 and the (Lowest Grade $=3.27$, Highest Grade $=4.87$ ) the level of faculty performance in terms of teaching new normal lifestyle of the professor of the Cavite State University in terms of Teaching Performance has a descriptive equivalent of Very Satisfactory. 


\section{EPRA International Journal of Research and Development (IJRD)}

LEVEL OF PERFORMANCE AND NEW NORMAL LIFESTYLE OF CVSU FACULTY

Table 7. Level of performance and new normal lifestyle of CvSU Faculty in terms of Teaching Effectiveness

\begin{tabular}{|l|l|l|l|}
\hline The Faculty of Cavite State University were able to: & Mean & SD & Remarks \\
\hline $\begin{array}{l}\text {.1. Inspire in their students a love of learning and also } \\
\text { understand how students best learn concepts, content and } \\
\text { skills. }\end{array}$ & 4.62 & 0.49 & Always \\
\hline $\begin{array}{l}\text { 2.Employing active learning teaching pedagogies regularly } \\
\text { during classes. }\end{array}$ & 4.60 & 0.49 & Always \\
\hline 3. Assigning frequent homework or problem sets. & 4.18 & 0.85 & Often \\
\hline 4. Provides feedback on the quality of student work. & 4.60 & 0.49 & Always \\
\hline 5. Contribute to student learning; & 4.72 & 0.45 & Always \\
\hline $\begin{array}{l}\text { Overall Mean }=4.54 \\
\text { Standard Deviation }=\mathbf{0 . 6 0 1} \\
\text { Verbal Interpretation = Very High }\end{array}$ & & \\
\hline
\end{tabular}

The performance and new normal lifestyle of CvSU faculty in terms of Teaching Effectiveness was generally very high. They contribute to student learning have $(M=4.72, S D=0.45)$ and inspire in their students a love of learning and also understand how students best learn concepts, content and skills with $(\mathrm{M}=4.62, \mathrm{SD}=0.49)$. They assigning frequent homework or problem sets with $(\mathrm{M}=4.18, \mathrm{SD}=0.85)$; and this item got the lowest rating. All item indicators got a verbal interpretation of high and very high, as disclosed by the overall mean of 4.54 and supported with standard deviation value of 0.601 .

Table 8. Level of new normal lifestyle of CvSU faculty in terms of Physical Distancing

\begin{tabular}{|l|l|l|l|}
\hline $\begin{array}{l}\text { The new normal lifestyle of the faculty in terms of } \\
\text { Physical distancing, the faculty were able to: }\end{array}$ & Mean & SD & Remarks \\
\hline $\begin{array}{l}\text { 1. Attended meeting face to face in a 6-meter distance } \\
\text { from each other. }\end{array}$ & 3.68 & 1.25 & Often \\
\hline 2. Practicing the skeletal working force at school. & 4.52 & 0.84 & Always \\
\hline $\begin{array}{l}\text { 3. Went to groceries store practicing the household } \\
\text { schedule. }\end{array}$ & 4.42 & 0.93 & Always \\
\hline $\begin{array}{l}\text { 4.Make use of public transportation going to the public } \\
\text { markets. }\end{array}$ & 3.24 & 1.60 & Sometimes \\
\hline 5.Paying Bills online to avoid the crowded areas. & 4.60 & 0.70 & Always \\
\hline $\begin{array}{l}\text { Overall Mean }=\mathbf{4 . 0 9} \\
\text { Standard Deviation }=\mathbf{1 . 2 2 7} \\
\text { Verbal Interpretation }=\text { High }\end{array}$ & & & \\
\hline
\end{tabular}

Legend:

\section{Scale Range Remarks}

5

4

3

2

1

$\begin{array}{ll}4.20-5.00 & \text { Always } \\ 3.40-4.19 & \text { Often } \\ 2.60-3.39 & \text { Sometimes } \\ 1.80-2.59 & \text { Rarely } \\ 1.00-1.79 & \text { Never }\end{array}$

Verbal Interpretation
Very High
High
Moderately High
Low
Very Low

The new normal lifestyle of CvSU Faculty in terms of Physical distancing was generally high. They paying Bills online to avoid the crowded areas have $(\mathrm{M}=4.60, \mathrm{SD}=0.70)$ and practicing the skeletal working force at school with $(\mathrm{M}=4.52, \mathrm{SD}=0.84)$. They make use of public transportation going to the public markets with $(\mathrm{M}=3.24$, $\mathrm{SD}=1.60$ ); and this item got the lowest rating. All item indicators got a verbal interpretation of moderately high to very high, as disclosed by the overall mean of 4.09 and supported with standard deviation value of 1.227. 


\section{EPRA International Journal of Research and Development (IJRD)}

Table 9. Level of new normal lifestyle of CvSU faculty in terms of Frequent Hand Sanitation

\begin{tabular}{|l|l|l|l|}
\hline $\begin{array}{l}\text { The new normal lifestyle of the Faculty in terms of } \\
\text { frequent hand sanitation, the Faculty were able to: }\end{array}$ & Mean & SD & Remarks \\
\hline $\begin{array}{l}\text { 1. Have alcohol in the bag to sanitize the hand from time } \\
\text { to time. }\end{array}$ & 4.90 & 0.36 & Always \\
\hline 2. Washed the hand frequently with clean water and soap. & 4.84 & 0.47 & Always \\
\hline $\begin{array}{l}\text { 3. Disinfect the school supplies issued by the property } \\
\text { custodian to avoid the germs. }\end{array}$ & 4.56 & 0.95 & Always \\
\hline 4. Washed the products bought from the grocery stores. & 4.66 & 0.66 & Always \\
\hline $\begin{array}{l}\text { 5. Provide a separate corner for shoes and other materials } \\
\text { at home before putting it inside the house. }\end{array}$ & 4.66 & 0.66 & Always \\
\hline $\begin{array}{l}\text { Overall Mean }=\mathbf{4 . 7 2} \\
\text { Standard Deviation }=\mathbf{0 . 6 5 8} \\
\text { Verbal Interpretation = Very High }\end{array}$ & & \\
\hline
\end{tabular}

Legend:

\section{Scale Range Remarks}

5

4

3

2

1

$\begin{array}{ll}4.20-5.00 & \text { Always } \\ 3.40-4.19 & \text { Often } \\ 2.60-3.39 & \text { Sometimes } \\ 1.80-2.59 & \text { Rarely } \\ 1.00-1.79 & \text { Never }\end{array}$

\section{Verbal Interpretation}

Very High

High

Moderately High

Low

Very Low

The new normal lifestyle of CvSU faculty in terms of Frequent Hand Sanitation was generally very high. They have alcohol in the bag to sanitize the hand from time to time have $(\mathrm{M}=4.90, \mathrm{SD}=0.36)$ and washed the hand frequently with clean water and soap with $(\mathrm{M}=4.84, \mathrm{SD}=0.47)$. They disinfect the school supplies issued by the property custodian to avoid the germs with $(\mathrm{M}=4.56, \mathrm{SD}=0.95)$; and this item got the lowest rating. All item indicators got a verbal interpretation of very high, as disclosed by the overall mean of 4.72 and supported with standard deviation value of 0.658 .

Table 10. Level of new normal lifestyle of CvSU faculty in terms of Wearing Face Mask and Face Shield

\begin{tabular}{|l|l|l|l|}
\hline $\begin{array}{l}\text { The new normal lifestyle of the Faculty in terms of } \\
\text { wearing of face mask and face shield, the Faculty were } \\
\text { able to: }\end{array}$ & Mean & SD & Remarks \\
\hline 1. Practice wearing mask as part of necessity. & 4.94 & 0.24 & Always \\
\hline 2. Make use of mask even inside the house. & 3.40 & 1.18 & Often \\
\hline 3. Washing the mask to use it again & 3.26 & 1.75 & Sometimes \\
\hline 4, Wearing face shield going to the public place & 4.88 & 0.39 & Always \\
\hline 5.Change face shield as needed. & 4.58 & 0.84 & Always \\
\hline $\begin{array}{l}\text { Overall Mean }=\mathbf{4 . 2 1} \\
\text { Standard Deviation }=\mathbf{1 . 2 6 1} \\
\text { Verbal Interpretation }=\text { Very High }\end{array}$ & & \\
\hline
\end{tabular}

Legend:

\begin{tabular}{|c|c|c|c|}
\hline Scale & \multicolumn{2}{|c|}{ Range Remarks } & Verbal Interpretation \\
\hline 5 & $4.20-5.00$ & Always & Very High \\
\hline 4 & $3.40-4.19$ & Often & High \\
\hline 3 & $2.60-3.39$ & Sometimes & Moderately High \\
\hline 2 & $1.80-2.59$ & Rarely & Low \\
\hline 1 & $1.00-1.79$ & Never & Very Low \\
\hline
\end{tabular}

The new normal lifestyle of CvSU faculty in terms of Wearing Face Mask and Face Shield was generally very high. They practice wearing mask as part of necessity have $(\mathrm{M}=4.94, \mathrm{SD}=0.24)$ and wearing face shield going to the public place with $(\mathrm{M}=4.88, \mathrm{SD}=0.39)$. They wash the mask to use it again with $(\mathrm{M}=3.26, \mathrm{SD}=1.75)$; and this 


\section{EPRA International Journal of Research and Development (IJRD)}

item got the lowest rating. All item indicators got a verbal interpretation of moderately high to very high, as disclosed by the overall mean of 4.21 and supported with standard deviation value of 1.261.

\section{EFFECT OF DEMOGRAPHIC PROFILE ON THE FACULTY PERFORMANCE OF CAVITE STATE UNIVERSITY}

Table 11. Significant effect of demographic profile on the faculty performance of Cavite State University

\begin{tabular}{|c|c|c|l|l|}
\hline \multicolumn{1}{|c|}{ Age } & Beta & t-value & p-value & \multicolumn{1}{|c|}{ Analysis } \\
\hline Teaching Performance & -1.537 & -6.559 & 0.000 & Significant \\
\hline Teaching Effectiveness & -0.902 & -2.806 & 0.007 & Significant \\
\hline Sex & & & & \\
\hline Teaching Performance & 0.124 & 1.933 & 0.059 & Not Significant \\
\hline Teaching Effectiveness & -1.031 & -11.71 & 0.000 & Significant \\
\hline Gender & & & & \\
\hline Teaching Performance & -0.031 & -0.205 & 0.838 & Not Significant \\
\hline Teaching Effectiveness & -1.183 & -5.714 & 0.000 & Significant \\
\hline Designation/Position & & & & \\
\hline Teaching Performance & -0.939 & -4.769 & 0.000 & Significant \\
\hline Teaching Effectiveness & -1.149 & -4.253 & 0.000 & Significant \\
\hline Years in Service & & & & \\
\hline Teaching Performance & -0.174 & -0.838 & 0.406 & Not Significant \\
\hline Teaching Effectiveness & -0.387 & -1.362 & 0.179 & Not Significant \\
\hline
\end{tabular}

Adjusted R-Square: 0.9110
F-value:
114.70
Sig.:
0.0000

Results from Table 11 revealed that the performance of the faculty Cavite State University had no effect on demographic profile. The beta coefficient indicates that for every standard deviation unit increase in Teaching Performance and Teaching Effectiveness, there is a corresponding unit increase in demographic profile. The t-value of Teaching Performance and Teaching Effectiveness, is partially significant having a p-value of less than 0.05 level of significance.

This means that the demographic profile to the performance of the professors of Cavite State University was influenced by Age and Gender.

Based on the data, it is shown that there is "a partial significant effect of demographic profile on the professor's performance of Cavite State University" at 0.05 level of significance. It shows that the null hypothesis stating that "There is no significant effect of demographic profile on the professor's performance of Cavite State University" is partially rejected, it can inferred that there is "a significant" effect between them.

Table 12. Significant effect of health and wellness program on the new normal lifestyle of CvSU faculty

\begin{tabular}{|l|c|c|c|c|}
\hline \multicolumn{1}{|c|}{ Stress Management } & Beta & t-value & p-value & Analysis \\
\hline Physical Distancing & -0.009 & -0.056 & 0.955 & Not Significant \\
\hline Frequently Hand Sanitation & 0.155 & 1.589 & 0.119 & Not Significant \\
\hline Wearing of Face Mask and Face Shield & 0.953 & 4.977 & 0.000 & Significant \\
\hline Smoking Cessations & & & & \\
\hline Physical Distancing & 1.660 & 6.318 & 0.000 & Significant \\
\hline Frequently Hand Sanitation & 0.099 & 0.611 & 0.544 & Not Significant \\
\hline Wearing of Face Mask and Face Shield & -0.387 & -1.209 & 0.233 & Not Significant \\
\hline Health Screening & & & & \\
\hline Physical Distancing & 0.329 & 3.258 & 0.002 & Significant \\
\hline Frequently Hand Sanitation & 0.000 & 0.001 & 0.999 & Not Significant \\
\hline Wearing of Face Mask and Face Shield & 0.638 & 5.190 & 0.000 & Significant \\
\hline Exercise Program Activities & & & & \\
\hline Physical Distancing & 0.362 & 1.249 & 0.218 & Not Significant \\
\hline
\end{tabular}




\section{EPRA International Journal of Research and Development (IJRD)}

\begin{tabular}{|l|l|l|l|l|}
\hline Frequently Hand Sanitation & -0.413 & -2.294 & 0.026 & Significant \\
\hline Wearing of Face Mask and Face Shield & 1.175 & 3.329 & 0.002 & Significant \\
\hline Nutrition Education & & & & \\
\hline Physical Distancing & 0.355 & 1.855 & 0.070 & Not Significant \\
\hline Frequently Hand Sanitation & -0.284 & -2.391 & 0.021 & Significant \\
\hline Wearing of Face Mask and Face Shield & 0.998 & 4.287 & 0.000 & Significant \\
\hline
\end{tabular}

Adjusted R-Square: 0.9626

F-value:

Sig.:

Results from Table 12 revealed that the new normal lifestyle of CvSU faculty had no effect on health and wellness program. The beta coefficient indicates that for every standard deviation unit increase in Physical Distancing, Frequently Hand Sanitation and Wearing of Face Mask and Face Shield, there is a corresponding unit increase in health and wellness program. The t-value of Physical Distancing, Frequently Hand Sanitation and Wearing of Face Mask and Face Shield is partially significant having a p-value of less than 0.05 level of significance.

This means that the health and wellness program to the new normal lifestyle of CvSU faculty was influenced by Health Screening, Exercise Program Activities and Nutrition Education.

Based on the data, it is shown that there is "a partial significant effect of health and wellness program on the new normal lifestyle of CvSU faculty" at 0.05 level of significance. It shows that the null hypothesis stating that "There is no significant effect of health and wellness program on the new normal lifestyle of CvSU faculty" is partially rejected, it can inferred that there is "a significant" effect between them.

\section{CONCLUSIONS}

Drawn the results of the study, the following results are set forth;

1. The null hypothesis stating the demographic profile of the Cavite State University has no significant effect in the effectiveness of their performance is accepted.

2. The null hypothesis stating that "There is no significant effect of demographic profile on the faculty performance of Cavite State University" is partially rejected, it can inferred that there is "a significant" effect between them.

\section{RECOMMENDATIONS}

Based on the findings and conclusion of the study, the following recommendations were drawn.

1. Instructors may find an interesting physical activity that could help them improve the health and wellness program that promotes healthy lifestyle.

2. The Faculty performance could maintain it's rating by means of attending webinars seminars that could inform them to enhance techniques of their teaching ability and effectiveness.

3. The researcher advice the members of the faculty to conduct a virtual meeting at least once a week for the update of the lessons, learners progress and health monitoring.

4. Health and wellness promotion in the new normal lifestyle of the instructors may continue to enhance that being healthy is most essential things that need to find time.

5. Healthy living has to consider the best thing that a faculty could have, for he or she could maintain a very satisfactory rate and an effective educator.

6. To the future researchers, a parallel study could be done in order to negate, confirm or improve the result of the present study in this time of pandemic 


\section{SJIF Impact Factor 2021: 8.013| ISI I.F.Value:1.241| Journal DOI: 10.36713/epra2016 ～ISSN: 2455-7838(Online) EPRA International Journal of Research and Development (IJRD)

\author{
Volume: 6 | Issue: 7 | July 2021
} \\ - Peer Reviewed Journal}

\section{REFERENCES}

1. Abioye, I. A., Omotayo, M. O., \& Alakija, W. (2011). Socio-demographic determinants of stigma among patients with pulmonary tuberculosis in Lagos, Nigeria. African Health Sciences, 11(S1), S100-S104. https://doi.org/10.4314/ahs.v11i3.70078.

2. A.E. Iancu, A. Rusu, C. Maroiu, R. Pacurar, L.P. Maricuoiu, The effectiveness of interventions aimed at reducing teacher burnout: a meta-analysis, Educ. Psychol. Rev. 30 (2) (2018) 373-396

3. Lodgher, J. Yang and U. Bulut, "An Innovative Modular Approach of Teaching Cyber Security across Computing Curricula," 2018 IEEE Frontiers in Education Conference (FIE), San Jose, CA, USA, 2018, pp. 1-5, doi: 10.1109/FIE.2018.8659040

4. Ahmad, A., Javaid, N., Mateen, A., Awais, M., \& Khan, Z. (2019). Short-Term Load Forecasting in Smart Grids: An Intelligent Modular Approach. Energies, 12(1), 164. doi:10.3390/en12010164

5. Ahmad FA, Karimi AA, Alboloushi NA, et al. Stress level of dental and medical students: comparison of effects of a subject-based curriculum versus a case-based integrated curriculum. J Dent Educ 2017;81: 534-44

6. Naghieh, P. Montgomery, C.P. Bonell, M. Thompson, J.L. Aber, Organisational interventions for improving wellbeing and reducing work-related stress in teachers, Cochrane Database Syst. Rev. (4) (2015) Cd010306.

7. Aidar FJ, Jacó de Oliveira R, Gama de Matos D, et al. A randomized trial of the effects of an aquatic exercise program on depression, anxiety levels, and functional capacity of people who suffered an ischemic stroke. The Journal of Sports Medicine and Physical Fitness. 2018 Jul-Aug;58(7-8):1171-1177. DOI: 10.23736/s0022-4707.17.07284-x.

8. Aidar FJ, Oliveira RJ, Silva AJ, Matos DG, Mazini Filho ML, Hickner RC, et al. The Influence of resistance exercise training on the levels of anxiety in ischemic stroke. Stroke Res Treat 2012;12:7-12

9. Allen, I. E., \& Seaman, J. (2013). Changing course: Ten years of tracking online education in the United States (No. ED541571). Sloan Consortium. http://sloanconsortium.org/publications/survey/changing_course_2012

10. Allotey P, Remme M, Lo S. Doing gender better: can the UN step up? Lancet 2019; published online May 30. http://dx.doi.org/10.1016/S0140-6736(19)30988-2

11. Ammendolia $C, \operatorname{Cot}^{\wedge}$ e P, Cancelliere C, Cassidy JD, Hartvigsen J, Boyle E, et al. Healthy and productive workers: using intervention mapping to design a workplace health promotion and wellness program to improve presenteeism. BMC Public Health. 2016;16:1190. https://doi.org/10.1186/s12889-016-3843-x

12. Andra, M. (2013). Kontribusi Kecerdasan Emosional dan Disiplin Kerja Terhadap Kinerja Guru SMP se- Kecamatan Pancung Soal Kabupaten Pesisir Selatan. Tesis Pasca Sarjana Universitas Negeri Padang. Padang: UNP.

13. Andersen KG, Rambaut A, Lipkin WI, Holmes EC, Garry RF. The proximal origin of SARS-CoV-2”, Nature Medicine 2020; 26: 450-455

14. Andresa R. Marinho-Buzelli, Graduate Department of Rehabilitation Science, University of Toronto, $160-500$ The Author(s) 2014 Reprints and permissions: sagepub.co.uk/journalsPermissions.nav DOI: 10.1177/0269215514556297

15. Asay GR, Homa DM, Abramsohn EM, Xu X, O'Connor EL, Wang G. Reducing smoking in the US federal workforce: 5 year health and economic impacts from improved cardiovascular disease outcomes. Public Health Rep. 2017;132(6):646e53. https://doi.org/10.1177/0033354917736300

16. Asian Pacific Nursing Lifestyle Journal (2020). Relationships among Lifestyle Awareness, Age, and Lifestyle-related Diseases in Healthy Japanese Community Residents.Asian Pac Isl Nurs J. 2020; 5(2): $103-110$. doi: $10.31372 / 20200502.1092$

17. Astrella JA. Return on investment: evaluating the evidence regarding financial outcomes of workplace wellness programs. J Nurs Adm. 2017;47(7-8):379e83. https://doi.org/10.1097/NNA.0000000000000499

18. Baier, F., Decker, A.T, Voss, T., Kleickmann, T., Klusmann, U., \& Kunter, M. (2019). What makes a good teacher? The relative importance of mathematics teachers' cognitive ability, personality, knowledge, beliefs, and motivation for instructional quality. British Journal of Educational Psychology, 89(4), 767-786. http://doi.org/10.1111/bjep.12256

19. Baker, S., Auld, G., Ammerman, A., Lohse, B., Serrano, E., \& Wardlaw, M. K. (2020). Identification of a Framework for Best Practices in Nutrition Education for Low-Income Audiences. Journal of Nutrition Education and Behavior. doi:10.1016/j.jneb.2019.12.007

20. Bastian, K.C., McCord, D.M., Marks, J.T., \& Carpenter, D. (2017). A temperament for teaching? Associations between personality traits and beginning teacher performance and retention. AERA Open, 3(1), 1-17. https://doi.org/10.1177/2332858416684764

21. Bessems, K. M. H. H., Linssen, E., Lomme, M., \& Van Assema, P. (2020). The Effectiveness of the Good Affordable Food Intervention for Adults with Low Socioeconomic Status and Small Incomes. International Journal of Environmental Research and Public Health, 17(7), 2535. doi:10.3390/ijerph17072535

22. Black MM, Delichatsios HK, Story MT (eds): Nutrition Education: Strategies for Improving Nutrition and Healthy Eating in Individuals and Communities. Nestlé Nutr Inst Workshop Ser. Nestlé Nutrition Institute, Switzerland/S. Karger AG., Basel, (C) 2020, vol 92, pp 119-129. doi: 10.1159/000499555 


\section{SJIF Impact Factor 2021: 8.013| ISI I.F.Value:1.241| Journal DOI: 10.36713/epra2016 ISSN: 2455-7838(Online) EPRA International Journal of Research and Development (IJRD)

\author{
Volume: 6 | Issue: 7 | July 2021
} \\ - Peer Reviewed Journal}

23. Bozkurt, A. (2019a). Intellectual roots of distance education: A progressive knowledge domain analysis. Distance Education, 40(4), 497-514. https://doi.org/10.1080/01587919.2019. 1681894

24. Cadore EL, Sáez de Asteasu ML, Izquierdo M. Multicomponent exercise and the hallmarks of frailty: considerations on cognitive impairment and acute hospitalization. Exp Gerontol 2019;122:10-14.

25. Chan ALY, Leung CC, Lam TH, Cheng KK. To wear or not to wear: WHO's confusing guidance on masks in the covid19 pandemic. BMJ opinion 2020. https:// blogs.bmj.com/bmj/2020/03/11/whos-confusing-guidance-masks-covid-19epidemic/.

26. Cheng, V. C. C., Wong, S.-C., Chuang, V. W. M., So, S. Y. C., Chen, J. H. K., Sridhar, S., ... Yuen, K.-Y. (2020). The role of community-wide wearing of face mask for control of coronavirus disease 2019 (COVID-19) epidemic due to SARS-CoV-2. Journal of Infection. doi:10.1016/j.jinf.2020.04.024

27. Chesak, S. S., Khalsa, T. K., Bhagra, A., Jenkins, S. M., Bauer, B. A., \& Sood, A. (2019). Stress Management and Resiliency Training for public school teachers and staff: A novel intervention to enhance resilience and positively impact student interactions. Complementary Therapies in Clinical Practice. doi:10.1016/j.ctcp.2019.08.001

28. Cinciripini, P. M., Karam-Hage, M., Kypriotakis, G., Robinson, J. D., Rabius, V., Beneventi, D., ... Blalock, J. A. (2019). Association of a Comprehensive Smoking Cessation Program With Smoking Abstinence Among Patients With Cancer. JAMA Network Open, 2(9), e1912251. doi:10.1001/jamanetworkopen.2019.12251

29. Clark, J., \& Horton, R. (2019). A coming of age for gender in global health. The Lancet. doi:10.1016/s01406736(19)30986-9

30. Contento I. Nutrition Education: Linking Research, Theory, and Practice. 3rd ed. Burlington, MA: Jones \& Bartlett Learning; 2015.

31. C. Taylor, J. Harrison, K. Haimovitz, R.W. Roeser, E. Oberle, K. Thomson, K. Schonert-Reichl, Examining ways that a mindfulness-based intervention reduces stress in public school teachers: a mixed-methods study, Mindfulness Mindfulness 7 (1) (2016) 115-129.

32. Cahill $K$, Lancaster T. Workplace interventions for smoking cessation. Cochrane Database Syst Rev. 2014;2:CD003440. https://doi.org/10.1002/14651858.CD003440.pub4

33. Carpenter CR, Banerjee J, Keyes D, Eagles D, Schnitker L, Barbic D, et al. Accuracy of Dementia Screening Instruments in Emergency Medicine: A Diagnostic Meta-analysis. Acad Emerg Med. 2019; 26:226-245. https://doi.org/10.1111/acem.13573 PMID: 30222232

34. Castellan RM, Chosewood LC, Trout D, Wagner GR, Caruso CC, Mazurek J, et al. Current intelligence bulletin 67: Promoting health and preventing disease and injury through workplace tobacco policies [Internet]. Atlanta, GA: Department of Health and Human Services, Centers for Disease Control and Prevention; 2015 [cited 2018 March 12]. Available from: https://www.cdc.gov/niosh/docs/ 2015-113/pdfs/FY15_CIB-67_2015-113_v3.pdf?id1/410.26616/ NIOSHPUB2015113

35. Cahapay, M. B. (2020). Social Distancing Practices of Residents in a Philippine Region with Low Risk of COVID-19 Infection. European Journal of Environment and Public Health, 4(2), em0057. https://doi.org/10.29333/ejeph/8455

36. Cartaud A, Ruggiero G, Ott L, Iachini T, Coello Y. Physiological Response to Facial Expressions in Peripersonal Space Determines Interpersonal Distance in a Social Interaction Context. Front Psychol. $2018 ; 9$. doi: 10.3389/fpsyg.2018.00657. pmid:29867639

37. Cartaud A, Ott L, Iachini T, Honoré J, Coello Y. The influence of facial expression at perceptual threshold on electrodermal activity and social comfort distance. Psychophysiology. 2020; e13600. doi: 10.1111/psyp.13600. pmid:32437046

38. Castex G, Dechter E, Lorca M. COVID-19: cross-country heterogeneity in effectiveness of non-pharmaceutical interventions. CEPR Covid Econ 2020;14:175-99

39. Christopher I. Jarvis , Kevin Van Zandvoort, Amy Gimma, Kiesha Prem, CMMID COVID-19 working group, Petra Klepac , G. James Rubin2 and W. John Edmunds" Quantifying the impact of physical distance measures on the transmission of COVID-19 in the UK"' Jarvis et al. BMC Medicine (2020) 18:124 https://doi.org/10.1186/s12916-02001597-8

40. Collerton J, Davies K, Jagger C, Kingston A, Bond J, Eccles MP, et al. Health and disease in 85 year olds: baseline findings from the Newcastle 85+ cohort study. BMJ (2014) 339:b4904. doi:10.1136/bmj.b4904

41. Dong E, Du H, Gardner L. An interactive web-based dashboard to track COVID-19 in real time. Lancet Infect Dis. 2020;20: 533-534. doi: 10.1016/S1473-3099(20)30120-1. pmid:32087114

42. Dorado, J. B., Azaña, G. P., Viajar, R. V., Ramirez, M. A. R. M., Ferrer, E. B., Buyco, N. G., ... Capanzana, M. V. (2020). Assessing school-lunch feeding and nutrition education strategy for healthier kids in selected Philippine public schools. Nutrition and Health, 026010602093046. doi:10.1177/0260106020930466

43. Emengo VN, Williams MS, Odusanya R, Uwemedimo OT, Martinez J, et al. (2020) Qualitative program evaluation of social determinants of health screening and referral program. PLOS ONE 15(12): e0242964. https://doi.org/10.1371/journal.pone.0242964 


\section{SJIF Impact Factor 2021: 8.013| ISI I.F.Value:1.241| Journal DOI: 10.36713/epra2016 ～ISSN: 2455-7838(Online) EPRA International Journal of Research and Development (IJRD)

\author{
Volume: 6 | Issue: 7 | July 2021
} \\ - Peer Reviewed Journal}

44. Essential environmental health standards in health care. Geneva: World Health Organization; 2008 (https://apps.who.int/iris/bitstream/handle/10665/43767/9789241547239_eng.pdf? sequence=1\&isAll owed=y, accessed 3 March 2020).

45. Emil Berg, M., and Terje Karlsen, J. (2014), "How project managers can encourage and develop positive emotions in project teams", International Journal of Managing Projects in Business, Vol. 7 No. 3, pp. 449-472

46. Ferguson $N$, Laydon D, Nedjati-Gilani $G$, Imai $N$, Ainslie $K$, Baguelin $M$, et al. Report 9-Impact of nonpharmaceutical interventions (NPIs) to reduce COVID-19 mortality And healthcare demand. Imperial College London; 2020.

47. Galvin, J. E., Tolea, M. I., \& Chrisphonte, S. (2020). What older adults do with the results of dementia screening programs. PLOS ONE, 15(7), e0235534. doi:10.1371/journal.pone.0235534

48. Glazov State Pedagogical Institute, Glazov, Russia, 2Moscow Social Pedagogical Institute, Moscow, Russia, 3 State University of Humanities and Social Studies, Kolomna, Russia, 4Moscow Aviation Institute (National Research University), Moscow, Russia, 5K.G. Razumovsky Moscow State University of technologies and management (the First Cossack University), Moscow, Russia. Humanities \& Social Sciences Reviews eISSN: 2395-6518, Vol 8, No 1, 2020, pp 272-279 https://doi.org/10.18510/hssr.2020.8138

49. González-Gómez, F., Guardiola, J., Rodríguez, Ó. M., \& Alonso, M. Á. M. (2012). Gender differences in e-learning satisfaction. Computers \& Education, 58(1), 283-290. https://doi. org/10.1016/j.compedu.2011.08.017

50. Greenhalgh T, Schmid MB, Czypionka T, Bassler D, Gruer L. Face masks for the public during the covid-19 crisis. BMJ 2020;369:m1435.

51. Grosemans, I., Boon, A., Verclairen, C., Dochy, F., \& Kyndt, E. (2015). Informal learning of primary school teachers: Considering the role of teaching experience and school culture. Teaching and Teacher Education, 47, 151e161. http:// dx.doi.org/10.1016/j.tate.2014.12.011.

52. Gupta, G. R., Oomman, N., Grown, C., Conn, K., Hawkes, S., Shawar, Y. R., ... Darmstadt, G. L. (2019). Gender equality and gender norms: framing the opportunities for health. The Lancet, 393(10190), 25502562. doi:10.1016/s0140-6736(19)30651-8

53. Happell, B., Scott, D., Nankivell, J., \& Platania-Phung, C. (2013). Screening physical health? Yes! But...: nurses' views on physical health screening in mental health care. Journal of Clinical Nursing, 22(15-16), 22862297. doi:10.1111/j.1365-2702.2012.04325.x

54. Heise L, Greene ME, Opper N, et al. Gender inequality and restrictive gender norms: framing the challenges to health. Lancet 2019; published online May 30. http://dx.doi.org/10.1016/S0140-6736(19)30652-X

55. Heymann J, Levy JK, Bose B, et al. Improving health with programmatic, legal, and policy approaches to reduce gender inequality and change restrictive gender norms. Lancet 2019; published online May 30. http://dx.doi.org/10.1016/S0140-6736(19)30656-7.

56. Hippich, M., Holthaus, L., Assfalg, R., Zapardiel-Gonzalo, J., Kapfelsperger, H., Heigermoser, M., ... Ziegler, A.-G. (2020). A Public Health Antibody Screening Indicates a 6-Fold Higher SARS-CoV-2 Exposure Rate than Reported Cases in Children. Med. doi:10.1016/j.medj.2020.10.003

57. Hui DS, Chow BK, Chu L, Ng SS, Lee N, Gin T, et al. Exhaled air dispersion during coughing with and without wearing a surgical or N95 mask. PLoS ONE 2012;7:e50845. 28.

58. Huang C, Wang Y, Li X, Ren L, Zhao J, Hu Y, et al. Clinical features of patients infected with 2019 novel coronavirus in Wuhan, China. Lancet. 2020;395:497-506. doi:10.1016/S0140-6736(20)30183-5.

59. Irwin, K., Edwards, K., \& Tamburello, J. A. (2015). Gender, trust and cooperation in environmental social dilemmas. Social Science Research, 50, 328-342. https://doi. org/10.1016/j.ssresearch.2014.09.002.

60. Kissler SM, Tedijanto C, Goldstein E, Grad YH, Lipsitch M. Projecting the transmission dynamics of SARS-CoV-2 through the postpandemic period. Science 2020

61. Khullar D, Maa J. The impact of smoking on surgical outcomes. J Am Coll Surg. 2012;215:418-426.

62. Koh, W. C., Naing, L., \& Wong, J. (2020). Estimating the impact of physical distancing measures in containing COVID-19: an empirical analysis. International Journal of Infectious Diseases. doi:10.1016/j.ijid.2020.08.026 .

63. Louws, M. L., Meirink, J. A., van Veen, K., \& van Driel, J. H. (2017). Teachers' self-directed learning and teaching experience: What, how, and why teachers want to learn. Teaching and Teacher Education, 66, 171183. doi:10.1016/j.tate.2017.04.004

64. Mansfield, C. F., \& Beltman, S. (2014). Teacher motivation from a goal content perspective: Beginning teachers' goals for teaching. International Journal of Educational Research, 65, 54e64. http://dx.doi.org/10.1016/j.ijer.2013.09.010

65. Maloney W, Taskin T. Determinants of social distancing and economic activity during COVID-19: a global view. CEPR Covid Econ 2020;13:157-77.

66. McCann P. The proactive elderly care team: dementia screening of over 20000 patients. Br J Hosp Med (Lond). 2019; 80:162-166.

67. Manabete SS, John CA, Makinde AA, et al. Job stress among school administrators and teachers in Nigerian secondary schools and technical colleges. Int J Educ Learning Devel 2016;4:1-9. 


\section{SJIF Impact Factor 2021: 8.013| ISI I.F.Value:1.241| Journal DOI: 10.36713/epra2016 ～ISSN: 2455-7838(Online) EPRA International Journal of Research and Development (IJRD)

68. Mahato, P., Tamang, P., Shahi, P., Aryal, N., Regmi, P., van Teijlingen, E., Simkhada, P. (2020). Effects of COVID-19 during lockdown in Nepal, Europasian Journal of Medical Sciences 2(2):1-5. City of Campbell River, SCR Framework: CampbellRiver's Integrated Sustainable Community Plan,(Campbell River, City of Campbell River, 2012, p.58).

69. Manning JB, Blandford
How Contextual Constraints Shape Midca A, Edbrooke-Childs $J$, Marshall How Contextual Constraints Shape Midcareer High School Teachers' Stress Management and Use of Digital Support Tools: Qualitative Study JMIR Ment Health 2020;7(4):e15416 doi: $10.2196 / 15416$

70. Marphatia, A. A., Ambale, G. S., \& Reid, A. M. (2017). Women's Marriage Age Matters for Public Health: A Review of the Broader Health and Social Implications in South Asia. Frontiers in Public Health, 5. doi:10.3389/fpubh.2017.00269

71. Murimi MW, Kanyi M, Mupfudze T, Amin MR, Mbogori T, Aldubayan K. Factors influencing efficacy of nutrition education interventions: a systematic review. J Nutr Educ Behav. 2017;49: 142-165.

72. Mushi, V., Shao, M. Tailoring of the ongoing water, sanitation and hygiene interventions for prevention and control of COVID-19. Trop Med Health 48, 47 (2020). https://doi.org/10.1186/s41182-020-00236-5

73. Papaioannou, A. G., Schinke, R. J., Chang, Y. K., Kim, Y. H., \& Duda, J. L. (2020). Physical activity, health and wellbeing in an imposed social distanced world. International Journal of Sport and Exercise Psychology, 16. doi:10.1080/1612197x.2020.1773195

74. Precey M. Teacher stress levels in England 'soaring', data shows. BBC News, File on 4. March 17, 2015. Available at: http://www.bbc.com/news/education-31921457 [Accessed 20 May, 2017].

75. Petersen, S. B., Arvesen, K. B., Penninga, L., Mikkelsen, C. S., \& Bjerring, P. (2020). Hand sanitation and the COVID19 pandemic. Forum for Nordic Dermato-Venerology, 25(2), 16-17.

76. https://www.medicaljournals.se/forum/articles/25/2/16-17.pdf

77. R.J. Davidson, A.W. Kaszniak, Conceptual and methodological issues in research on mindfulness and meditation, Am. Psychol. 70 (7) (2015) 581-592.

78. Ross BM, Barnes DM. Self-determination theory with application to employee health settings. Workplace Health Saf. 2018;66(8):367e72. Journal Articles. https://doi.org/10.1177/2165079917749863

79. Rose, D., Heller, M. C., \& Roberto, C. A. (2019). Position of the Society for Nutrition Education and Behavior: The Importance of Including Environmental Sustainability in Dietary Guidance. Journal of Nutrition Education and Behavior, 51(1), 3-15.e1. doi:10.1016/j.jneb.2018.07.006

80. Sposato W. Japan's Halfhearted Coronavirus Measures Are Working Anyway. Foreign Policy. May 14. 2020. https://foreignpolicy.com/2020/05/14/japancoronavirus-pandemic-lockdown-testing/.

81. Susanto, A. (2016). Manajemen Peningkatan Kinerja Guru: Konsep, Strategi, dan Implementasinya. Jakarta: Prenadamedia Group.

82. Van Bavel JJ, Baicker K, Boggio PS, Capraro V, Cichocka A, Cikara M, et al. Using social and behavioural science to support COVID-19 pandemic response. Nature Human Behaviour. Nature Research; 2020. pp. 460-471. doi: 10.1038/s41562-020-0884-z.

83. Sadana, R., Blas, E., Budhwani, S., Koller, T., \& Paraje, G. (2016). Healthy Ageing: Raising Awareness of Inequalities, Determinants, and What Could Be Done to Improve Health Equity. The Gerontologist, 56(Suppl 2), S178S193. doi:10.1093/geront/gnw034

84. Seifert, Colleen M; Chapman, Larry S; Hart, Joseph K; Perez, Paul (2012). Enhancing Intrinsic Motivation in Health Promotion and Wellness. American Journal of Health Promotion, 26(3), TAHP-1-TAHP12. doi:10.4278/ajhp.26.3.tahp

85. Sevilla, Consuelo G. et. al (2007). Research Methods. Rex Printing Company. Quezon City'

86. Sheeran P, Klein WM, Rothman AJ. Health Behavior Change: Moving from Observation to Intervention. Annu Rev Psychol. 2017; 68:573-600. https://doi.org/10.1146/annurev-psych-010416-044007 PMID: 27618942

87. Smith, M. and Bititci, U. (2017). Interplay between performance measurement and management, employee engagement and performance. International Journal of Operations and Production Management, 37, pp. 1207-1228

88. Sorensen LT. Wound healing and infection in surgery: the clinical impact of smoking and smoking cessation: a systematic review and meta-analysis. Arch Surg. 2012;147:373-383.

89. South Korea takes new measures to have enough face masks domestically amid coronavirus. abc News. 2020. https://abcnews.go.com/International/ south-korea-takes-measures-face-masks-domestically-amid/story?id=69254114

90. Ssegawa, J.K. and Muzinda, M. (2016), "Using RBM approach in managing projects beyond the development sector", International Journal of Managing Projects in Business, Vol. 9 No. 2, pp. 337-363.

91. Tehseen, S., \& Ul Hadi, N. (2015). Factors Influencing Teachers' Performance and Retention. Mediterranean Journal of Social Sciences. doi:10.5901/mjss.2015.v6n1p233

92. To KK, Tsang OT, Leung WS, Tam AR, Wu TC, Lung DC, et al. Temporal profiles of viral load in posterior oropharyngeal saliva samples and serum antibody responses during infection by SARS-CoV-2: an observational cohort study. Lancet Infect Dis 2020. 


\section{SJIF Impact Factor 2021: 8.013| ISI I.F.Value:1.241| Journal DOI: 10.36713/epra2016ＩSSN: 2455-7838(Online) EPRA International Journal of Research and Development (IJRD)

\author{
Volume: 6 | Issue: 7 | July 2021
} \\ - Peer Reviewed Journal}

93. Tolentino, Lean Karlo S and Isoy, John Erick L and Bulawan, Kayne Adriane A and Co, Mary Claire T and Monreal, Caryl Faye C and Vitto, Ian Joshua W and Padilla, Maria Victoria C. and Quijano, Jay Fel C and Jorda, Romeo Jr L and Velasco,

94. Ugwoke, S. C., Eseadi, C., Igbokwe, C. C., Chiaha, G. T. U., Nwaubani, O. O., Orji, C. T., ... Abugu, L. I. (2017). Effects of a rational-emotive health education intervention on stress management and irrational beliefs among technical college teachers in Southeast Nigeria. Medicine, 96(31), e7658. doi:10.1097/md.0000000000007658

95. United States Agency for Intenational Development. Promoting hygiene and hand-washing through community hygiene monitoring units | SPRING. https://www.spring-nutrition.org/about-us/activities/promoting-hygieneand-hand-washingthrough-community-hygiene-monitoring-units. Accessed 2 June 2020.

96. University of Waterloo "Canadian Index of Wellbeing,"

97. https://uwaterloo.ca/canadian-indexwellbeing/about-canadian-index-wellbeing (accessedMay 1, 2013).

98. Vandegrift R, Bateman AC, Siemens KN, Nguyen M, Wilson HE, Green JL, et al. Cleanliness in context: reconciling hygiene with a modern microbial perspective. Microbiome 2017; 5: 76.

99. Van den Broucke, S. (2020). Why health promotion matters to the COVID-19 pandemic, and vice versa. Health Promotion International (online first) 10.1093/heapro/daaa042 https://www.ncbi.nlm.nih.gov/pmc/articles/PMC7184433/pdf/daaa042.pdf

100. Van de Grift, W. J. C. M., Van der Wal, M., \& Torenbeek, M. (2011). Ontwikkeling in de pedagogisch didactische vaardigheid van leraren in het basisonderwijs [Development of teachers' teaching skills in primary education]. Pedagogische Studie€en, 88, 416e432

101. Visser, M., Wijnhoven, H. A. H., Comijs, H. C., Thomése, F. G. C. F., Twisk, J. W. R., \& Deeg, D. J. H. (2018). A Healthy Lifestyle in Old Age and Prospective Change in Four Domains of Functioning. Journal of Aging and Health, 089826431877443. doi:10.1177/0898264318774430

102. Wallace, S. P. (2012). Social determinants of health inequities and health care in older age. In T. R. Prohaska, L. A. Anderson, \& R. H. Binstock (Eds.), Public health for an aging society. Baltimore, MD: Johns Hopkins University Press.

103. Weber AM, Cislaghi B, Meausoone V, et al. Gender norms and health: insights from global survey data. Lancet 2019; published online May 30. http://dx.doi.org/10.1016/S0140-6736(19)30765-2

104. Whittaker R, McRobbie H, Bullen C, Rodgers A, Gu Y. Mobile phone-based interventions for smoking cessation. Cochrane Database Syst Rev. 2016;4: CD006611. https://doi.org/10.1002/14651858.CD006611.pub4

105. White MS, Burns C, Conlon HA. The impact of an aging population in the workplace. Workplace Health Saf. 2018;66(10):493e8. Journal Articles. https://doi.org/10.1177/2165079917752191

106. Winstein, C. J., Stein, J., Arena, R., Bates, B., Cherney, L. R., Cramer, S. C., Deruyter, F., Eng, J. J., Fisher, B., Harvey, R. L., Lang, C. E., MacKay-Lyons, M., Ottenbacher, K. J., Pugh, S., Reeves, M. J., Richards, L. G., Stiers, W., \& World Health Organization and the United Nations Children's Fund (UNICEF), 2020. Some rights reserved. This work is available under the CC BY-NC-SA 3.0 IGO

107. WHO. Coronavirus disease (COVID-19) Situation Report-132. Geneva: World Health Organization; 2020

108. Yamagishi, K., \& Iso, H. (2017). The criteria for metabolic syndrome and the national health screening and education system in Japan. Epidemiology and Health, 39, e2017003. doi:10.4178/epih.e2017003

109. Yates C, Allen T, Joseph J, Lantagne M. Evidence Synthesis Humanitarian Evidence Programme WASH interventions in disease outbreak response -2017. https:// reliefweb.int/sites/reliefweb.int/files/resources/OX-HEP-WASHPrint.pdf. Accessed 11 May 2020.

110. Yusuf FA, Olufunke YR, Valentine MD. Causes and impact of stress on teachers' productivity as expressed by primary school teachers in Nigeria. Creat Educ 2015;6:1937-42.

111. Zidane, Y. J.-T., \& Olsson, N. O. E. (2017). Defining project efficiency, effectiveness and efficacy. International Journal of Managing Projects in Business, 10(3), 621-641. doi:10.1108/ijmpb-10-2016-0085 